\title{
Western Misperception when Deterring Russia: Cultural and Linguistic Factors
}

\author{
Viljar Veebel ${ }^{1}$, Liia Vihmand ${ }^{2}$, Illimar Ploom ${ }^{3} \&$ Raul Markus ${ }^{4}$ \\ ${ }^{1}$ Baltic Defence College, Tartu, Estonia \\ 2 Tartu University, Tartu, Estonia \\ ${ }^{3}$ Estonian Military Academy, Tartu, Estonia \\ ${ }^{4}$ Tallinn University of Technology, Tartu, Estonia \\ Correspondence: Viljar Veebel, Baltic Defence College, Riia 12-402, Tartu 51013, Estonia. E-mail: \\ viljar.veebel@ut.ee
}

Received: June 24, 2020

doi:10.5539/jpl.v13n3p151
Accepted: July 13, $2020 \quad$ Online Published: August 17, 2020

URL: https://doi.org/10.5539/jpl.v13n3p151

\begin{abstract}
Policy-making discourses of both Moscow and the capitals of Western countries are full of mutual misperceptions, mirror imaging, and attribution of non-existent intentions and capabilities. Although the concepts of deterrence of Western countries and Russia partially overlap, there is also a huge area where they operate in "parallel universes." Furthermore, a lot of strategic culture in association with deterrence is produced not for operational or functional purposes, but to please local political or military elite. To answer the question which improvements are needed in the future to actually deter Russia and to avoid further aggression on the Russian side, first, Russia can be deterred only in the language they understand: Russia needs to understand the threat, and it needs to have meaning for them.
\end{abstract}

Keywords: European Union, NATO, Russia, deterrence, coercion

\section{Introduction: Why Are the Russians not Deterred Despite Systematic Western Efforts?}

Russia's systematic confrontation with Western countries since Crimean annexation has lasted for five years already, with variable intensity. During that time, Russia has not shown any signs of regret or deterrence despite the efforts of the West, including economic sanctions, international condemnation, political isolation and stigmatization of Russia and Russian political elite. This is something that the Western countries have difficulty in understanding. Why do Russians not beg for forgiveness for their actions in Ukraine, Georgia, and Syria? Why do they not get the message that they should be deterred? Why does the country not understand that it is not going to be one of the global great powers, and why they do not seek compromise with the West? Finally, why do Russians not remove Vladimir Putin from power?

This confusion of Western politicians and analysts arises from the rationale that "Russia should be deterred because we would be deterred if we were in their place." This misconception is directly linked to the Western approach, which expects the psychological behavioral patterns of the West and Russia to overlap at least in most crucial aspects. In this way, Russia is expected to adopt Western normative values and to accept the widely prevalent postmodern security narrative prioritizing political and social stability, economic welfare, peaceful solutions to conflicts, and a rules-based global order. The extension of Western normative values and fears of the Russian political elite is, for example, reflected in the statements of many former and current high-level politicians of the EU institutions (Veebel 2019). Moreover, the Western deterrence model is often based on the constructivist approach where certain issues are socially constructed as security threats (Buzan 1991). In practical terms, these issues are just primarily associated with topics that people are more informed about or that engage more with the public in terms of values and norms. In this way, the recent efforts of the Western countries to deter Russians have not caused any actual fear in the opponent but have served mostly as a sign of assurance or resilience for the Western countries themselves.

This article aims to critically assess the reasons why the Western deterrence model has not caused any actual fear in Russia. To quote Rebecca Hersman, "deterrence is, at its core, a dialogue — and, as such, rests on three questions: Can we be heard? Are we listening? And are we understood?" (Hersman 2017). In this respect, the focus of this article is on the following questions: Do Russians understand the meaning of deterrence at all? What are they not 
afraid of? Does the country have any "red lines" and "glass roofs"? And what could actually deter Russia and Russian political elite?

Therefore, the main contribution of the article lies in a comprehensive analysis of what are the fundamental misperceptions of the Western countries when trying to deter Russia. Until now, both the EU's political elite and the transatlantic military community have avoided any direct criticism concerning the shortcomings of the current security approach of the Western countries. Instead of this, a view has been taken that the West's current security model is the best possible way of deterring Russia, as well as that the more quantitative resources are allocated, the more effective deterrence will be. Furthermore, those who have dared to question the effectiveness of the current security approach of the West were sometimes labelled as being supporter of Russia. However, a critical view on the shortcomings of the Western deterrence model could help to take control over the security situation in Europe again.

\section{Should We Expect the Behavioural Patterns of West and That of Russia to Overlap?}

The vision, that Russia is interested in the adoption of Western normative values is directly linked with the selfimage of NATO and EU member states as normative power implementers. Russia as many other countries are in this model seen as target countries to be forced or persuaded for the export of certain norms, rules, and practices such as democracy, social justice, commitment to human rights, and fundamental freedoms to other countries. Changing "the other" is essential aim of the normative power (Gerrits 2009).

Normative power concept based on neo-imperial motivations dates back to the 1930s. However, the idea about the "unique" power of the EU and NATO has received particular attention since the late 1990s and successful transition of former Soviet bloc states to Western value space. Ukraine and Russia in this model are seen nothing more specific than the rest of former Soviet republics.

Ian Manners describes that the norm diffusion is shaped by six channels, including contagion (unintentional diffusion), informational factor (strategic and declaratory communications), procedural factor (institutionalization of relationship by the EU or NATO), transference (exchange of benefits by imposer and the third parties), overt (physical presence in the third countries or international organizations), and cultural filters (cultural diffusion and political learning in the third countries and organizations) (Manners 2002). Based on that ground, both the European Union and NATO are expected to have power to change or protect the norms of international relations.

The diffusion of Western norms is also closely related to the theory of external governance, which operates as a form of interdependence in which internal rules are extended beyond the formal membership (Veebel et. al. 2014). The theory has become one of the main explanations for integration of other countries into the system of European rules and regulations. Whereas in earlier studies from late 1990s external governance has been related to the Central and Eastern European countries and the EU Eastern Enlargement only (Lavenex 2004), later studies have associated it with all of the countries participating in the European neighborhood policy. Although Russia is not a part of the European neighborhood policy (ENP) as such, the country takes part in cross-border cooperation activities under the ENP (European Commission 2019).To sum up, it is expected that through various channels and wide-ranging contacts the EU succeeds to promote European norms and values in many countries, including Russia. At the transatlantic level, credible deterrence is expected to act as a guarantee for stability and peace in the Euro-Atlantic region. According to the NATO Alliance's strategy, "no one should doubt NATO's resolve if the security of any of its members were to be threatened" (NATO 2012). It is expected that the combination of the Alliance's nuclear and conventional capabilities would persuade the opponents that aggression causes costs that are higher than potential gains (NATO 2015 and NATO 2017).

To conclude, Western countries have systematically developed multilateral international order, which is not only based on their values but is also expected to project those values to other countries by using "stick and carrot" approach. Additionally, it is seen as irrational for neighboring powers to not accept this model, even when Russia is not the only one openly rejecting all the elements of normative power and external governance and seeing itself as regional power-centre and source of external governance. Recent Russian attempts to challenge the current international security order have not demonstrated discouragement and deterrence. Without any overt fear of retaliation, we have seen Russia's aggression against its neighbors that were planned and executed with great decisiveness, sophistication, initiative, and agility. This brings us to the question of whether Russians understand the meaning of deterrence at all.

\section{Do Russians Undertand the Meaning of Deterrence?}

A broader understanding of how deterrence could or is expected to work in Russia has a lot to do with what Russians understand by deterrence, as well as how things are translated in the Russian language and how society 
is ready to accept certain non-native thinking concepts. Scholars have identified three stages in the evolution of Russian post-Cold War deterrence thinking. In the first stage, the theory of de-escalation emerged in 1999 with a focus on how to make use of nuclear capabilities in the most efficient way possible against a conventionally superior adversary. In the second stage in the 2000s, the focus of the concept shifted towards strategic deterrence, referring to the question of how nuclear and conventional capabilities could be combined to deter both conventional and nuclear threats. In the third stage since 2010s, the idea behind strategic deterrence has been expanded, including also non-nuclear and non-military components (Ven Bruusgaard 2016, 7-26).

In this light, initially the term deterrence was associated with nuclear assets in Russia. However, some doubts about the country's nuclear capabilities have contributed to the development of a more comprehensive approach to deterrence in Russia in the following decades with the aim of offering Russia other tools next to nuclear capabilities to prevent and shape conflict. For example, already in 2010, the Russian Military Doctrine placed more emphasis on conventional forces, communication, and command and control systems (Sokolov 2010. Intriguingly, it has been argued that Russia learned to use non-military capabilities from observing Western activities since the end of the Cold War, e.g., in Eastern Europe and the Middle East (Loukianiva Fink 2017). Further doctrinal documents from 2015 onward have only confirmed this approach, describing a large variety of non-military, non-nuclear, and nuclear capabilities in Russia to deter adversaries (Śliwa, Veebel and Lebrun 2018). However, despite this the strategic deterrence of Russia is still a strategy which is to a large extent based on convincing an opponent of a credible threat of using military force (Loukianiva Fink 2017). To quote the Russian National Security Strategy, "Interrelated political, military, military-technical, diplomatic, economic, informational, and other measures are being developed and implemented in order to ensure strategic deterrence and the prevention of armed conflicts. These measures are intended to prevent the use of armed force against Russia and to protect its sovereignty and territorial integrity. Strategic deterrence and the prevention of armed conflicts are achieved by maintaining the capacity for nuclear deterrence at a sufficient level, and the Russian Federation Armed Forces, other troops, and military formations and bodies at the requisite level of combat readiness" (Russian National Security Strategy, 2015). It should be also highlighted that Russian military analysts differentiate between regional and global deterrence. Regional deterrence aims to deter localised interstate conflict with Russia or its allies. Global deterrence is aimed to deter possibly existential conflict between great powers (Frear, Kulesa and Raynova, 2018).

Thus, in principle, Russia should understand the essence of deterrence in a similar way as the Western countries do because the deterrence models of both adversaries include military and non-military, nuclear and non-nuclear capabilities as a response to potential threats. However, there might be some confusion in Russia, as regards precise terms are to be considered (Veebel 2018). The term deterrence in Russian, sderzivanie, does not exactly include all components of deterrence but covers mostly deterrence by denial in combination with resilience. The aspects related to deterrence by punishment or deterrence by lack of ambitions are, however, missing. Furthermore, in the Russian language, deterrence is a purely reactive concept which is historically associated with Russia's fight against Napoleon or Hitler because in the past sderzivanie has been used to refer to the idea that the opponent is forced to step out of the conflict after it has suffered heavy losses (Veebel and Vihmand 2020). Coercion as an alternative term to deterrence by punishment is not used in Russian military language at all. Russians, however, use the term prinuzdhenie which more or less reflects the meaning of compulsion and is understood as a forceful proactive action to indicate change (Adamsky 2018). All this brings us to the next question of why are Russians not afraid, assuming that despite some language specificities, they still understand the basic essence of deterrence in a similar way to the Western countries. The answer could be found in unrealistic expectations of the Western countries, concerning that of which Russia is afraid.

\section{Misperception about Russian Fears and Concerns}

In principle, there are two fundamental misperceptions that the Western countries have, when trying to deter Russia. First, Russia is expected to be afraid of losing the rule-based world security order, and second, Russia is expected to demonstrate good will and cooperative mentality to improve the relations with the West.

The first expectation that Russia is afraid of losing the rules-based world security order is misleading in the way that the Russian leadership seems not to put their stakes in peaceful coexistence, and acceptance of Western values. On the one hand, since the outbreak of the Ukrainian conflict, the Russian political elite has constantly sent signals to the international community that the country does not violate the fundamental principles of international law but instead that Crimea and Russia share a common history and pride. Furthermore, Vladimir Putin argues that Crimea has always been an inseparable part of Russia (to quote Vladimir Putin, "large sections of historical South of Russia"), and that "this conviction is based on truth and justice and was passed from generation to generation, over time, under any circumstances, despite all the dramatic changes our country went through during the entire 
20th century" (Putin 2014). On the other hand, while actively testing the low-intensity options for hybrid destabilization of the region, Russia has simultaneously blamed Western countries for interfering in home affairs of other countries as well as for the abuse of the normative power in the international arena, referring to the "attempts to maintain the dominance of the US and its allies in global affairs by carrying out a policy of containment of Russia," as stated in the Russia's national security strategy (Russian National Security Strategy, 2015). This strategy document also points to the United States of America and the European Union as supporters for the anti-constitutional coup d'etat in Ukraine. Similarly, "colour revolutions" in Georgia, Ukraine, and Kyrgyzstan in 2003-2005 and the Arab Spring in 2010-2012 have been described in Russia as examples of disruptive Western policy (Frear, Kulesa and Raynova, 2018). Moreover, already in 2007 in the Munich Security Conference, Vladimir Putin stressed the failure of the unipolar world order and pointed to double standards of the Western democracies while dictating Russia towards democratic transition (Rahim 2018).

Next to that, from Russia's perspective, all more or less peaceful attempts the country has made in 2015-2017 have been rejected by the West with a reference to Russia's aggressive behavior in the past "until further compliance is witnessed." Otherwise, in those cases where Russia has visibly used military forces like in Syria, the country has been "taken into the club" again by the international community. This speaks in favor of the use of "escalate to de-escalate" strategy, meaning that the international community should actually not be surprised about Russia's tactics to constantly plan new scenarios of conflict escalation both in existing conflict zones and in new areas. Furthermore, Russia has not been properly punished for using the "escalate to de-escalate" model, so most likely they will continue to use it (Veebel and Sliwa 2019). The models of the OSCE and UN also support this view. In case of Ukraine and Syria, Russia clearly turned into a pro-active hybrid actor (Ploom, Sazonov and Veebel 2019).

In this respect, it is interesting that the Russian discourse often uses the term struggle (bor'ba) to refer to various forms of strategic interactions. For example, their military dictionary includes terms like informational struggle, radio-electronic struggle, diplomatic struggle, ideological struggle, economic struggle, or armed struggle (Rogozin 2011). Thus, it seems that for Russians a desirable positive situation is a dynamic and agile struggle rather than a static comfort zone hoping that world is and will be peaceful.

Seen in this light, there is actually no reason to expect that current Russian leadership would change their mind and be interested in maintaining the current rule-based world security order. Russia is by no means interested in compliance with Western demands and in maintaining the current international security order. At the same time, when Western countries make calculations, they somehow sum up those two minuses and get one plus. For example, while the West considers political embargo as a last warning for Russia, then Russia interprets it as carte blanche for things that the country needed to do.

The second presumption that Russia is expected to demonstrate good will to improve the relations with the West is also misleading in many ways. There seems to be an overall misperception that Russian political elite is ready to make an offer of good will first to seek for forgiveness by the international community, without expecting anything in return other than Western patronizing statements that "it takes more to be taken back to the club" (Elenkov 1998). In practice, such an expectation has only very little historical proof. On the contrary, one of the key principles of the foreign policy of the former Soviet Union was to reject all kind of offers of compromise or good will, especially in regards to territorial or border disputes. Thus, at least based on historic traditions, there is no reason to believe that normalization of mutual relations between Russia and the West with "one-sided gifts" could take place. Furthermore, there is a popular expression that Russians have, referring to the statement of Mr. Andrei Gromyko, the Soviet Union's Minister of Foreign Affairs during the Cold War during the disputes with the members of the Japanese delegation over the Kuril Islands, "we are as big as we are because we never return any territories if not forced" (Veebel 2017). However, Russia's good will could appear if potential increase in reverence and respect is included in the formula: accordingly, Russians could potentially be ready to make "gifts," should they potentially gain more respect because of this step. However, nothing like this is unlikely to happen under pressure to be degraded (Timofeev 2016).

In principle, Russia's good will to improve relations with the West could potentially arise also due to country's desire to avoid political isolation or economic recession. However, this assumption too is mostly unrealistic. The first part of this assumption would suggest that Russia is ready to sacrifice its sovereignty to get higher diplomatic influence and inclusion. However, this assumption simply does not take into account the fact that Western countries are only one potential partner out of many in the Russian diplomatic and political landscape. In real terms, Russia has numerous "client states" located both in its neighborhood (like Belarus and Armenia) as well as in Latin America (like Venezuela). Furthermore, Russia has big economic partners at their border (China) or a bit further away (India). Should, e.g., the President of the United States or the Chancellor of Germany reject to meet Vladimir 
Putin, there are other options for the Russian President to boost his ego. Furthermore, several recent developments such as those in Syria and Venezuela have clearly shown that Russia dictates the political agenda of the international community because it is Russia who fuels the conflicts and later on rushes straight in to solve it under the noses of Western countries. This is most likely also the reason why, for example, both Donald Trump and Angela Merkel have recently found time and motivation for several bilateral meetings with Vladimir Putin. Thus, even if Russia is officially banned "from the negotiating table," unofficially, everyone still counts on Russia.

The second part of this expectation suggesting that Russia's political elite does not want to drag the country into deep economic recession and to increase poverty in Russia seems to be overestimated, too. It is expected that Russia is willing to trade its sovereignty and to lose control over its territories for the non-application of economic sanctions. The economic sanctions the West has imposed on Russia from 2014 on after the annexation of Crimea prove otherwise. The Russian economy has already faced economic recession, weaker direct investment, the rouble losing its value, soaring capital flight, and high inflation rates for some period because of a combination of economic sanctions, a trend of global stagnation, and oil price dynamics. However, despite this economic pressure, no success has been achieved internationally in solving the conflict in Ukraine (Veebel and Markus 2016). This means that the Russian political elite is not even considering trading sovereignty for economic benefits but only economic benefits for more political influence. Furthermore, about 22 percent of the Russian population is currently living in poverty anyway, meaning that one cannot be afraid of losing something what one has never experienced, such as economic welfare and security. Russians have already felt difficult times in 2015-2017, as one-quarter of Russian companies cut wages or even skipped payments to the employees, the average wage has dropped and so on, but Vladimir Putin was still elected as a Russian President in 2018 for fourth term with more than 76 percent of the vote (BBC 2018).

The latter also confirms that, contrary to the West, Russia does not need reason or justification for the use of force. Whereas, in principle, the West tries to avoid any unprovoked use of force with the purpose of avoiding the loss of a moral "upper hand," legitimacy, and public support, Russians consider a successful domination over its neighbors as something that is self-justifying and self-legitimizing, based on vital national interests. Russia is fully based on the concept of raison d'état, where vital national interests do not need any additional justification. Furthermore, a strategy of an unforeseen and sudden escalation belongs to the traditional success models of the Russian society, as well as readiness to escalate without any reason is considered as a sign of strength and agility. Being pre-emptive and pro-active constitutes a normal feature of the Russian foreign policy and this approach is used systematically.

Since there seems to be no socio-political comfort zone to maintain, no economic welfare to lose, and no rulesbased global order to preserve in Russia today, a threat to take away the cornerstones of a Western welfare state clearly does not work for deterring Russia. All this brings us to the question of whether the country has any "red lines" and "glass roofs," which could cause the country to step off the confrontation with the West.

\section{Does Russia Have "Red Lines" and "Glass Roofs" in Its Confrontation with the West?}

There seems to be an expectation in both security discourse and public relations discourse of Western countries that the Russian leadership behaves impulsively or sometimes even psychopathically without understandable rational calculations: it's like they do not realize the supremacy of NATO and the European Union in each possible category.

However, in international politics, both the balance of powers and supremacy depend on the characteristics that are under consideration. For example, as regards full combat readiness of conventional units during 72 hours in the Central and Eastern European region, Russian experts are convinced that Russia has an advantage, even when Poland is included in the calculation. Should also both Russia's ability to cover huge areas in Central and Eastern Europe by the A2AD-bubble from its own territory and the country's ability to use strategic depth for manoeuvres taken into account, there is very little reasons to expect that Russian military planners could be deterred. The same applies to the economic situation. In 2018, after four years of the implementation of sanction the Russian economy has grown faster (1.5 percent) than that of Germany (1.1 percent), Italy ( 0.7 percent) or France (1.4 percent). Furthermore, it does not help that news articles are published revealing that the ninth tank brigade of the German Bundeswehr located in Münster has only nine operational Leopard 2 type of tanks, even though it was promised to have 44 tanks ready for the VJTF, and three Marder armoured infantry vehicles instead of 14, as has been promised (Ploom and Veebel 2019). In this respect, Russians seem to be convinced that they have nothing to fear and by gradual escalation actually make very reasonable choices, no matter how unpleasant and uncomfortable that may be for the West.

Current expectations of Western countries about the "red lines" and "glass roofs" of the Russian political and 
military elite do not have much reference in the Russian society. For example, it is expected that because the United States has restricted the use of nuclear assets only on retaliatory and strategic purposes, Russia would do the same and will not look for useful practical combinations for tactical use of nuclear assets or for threatening purposes. There is no official doctrine of the regional or tactical use of nuclear assets, however, there could be a regional strategic scenario, e.g., to signal readiness to do so.

At the same time, Russian political and military elite do not find any benefit of the Western definitions for "red lines" or "glass roofs", just revealing to your opponents, where your limits are and making it easier to outplay you. What is a proper action is clearly seen differently by the adversaries. For example, whereas Western countries consider it immoral to attack small and vulnerable neighbours (like the Baltic countries, in case of Russia), the Russian military and political leadership sees it purely as an opportunity to gain advantage in the "contest" of regional or even global domination. Russia's recent "wars" or displays of force have been justified using the Soviet-era logic of waging war in order to avoid war (Kolesnikov 2016). Furthermore, Russian experts have admitted that conflict escalation in the Baltics would be most likely happening not for local reasons but only then when it should be sufficiently beneficial and influential to challenge the global rule-based security order.

The more and more extensive Zapad-exercises have currently been the direct outcome of how Russia understands the actions what the country needs to do to deter the West. This is something what Russia calls "forceful measures" of strategic deterrence: a system of interlinked measures of both forceful, i.e,. nuclear and non-nuclear, and nonforceful character. This type of deterrence may include a display of power to prevent escalation or the limited use of force as a radical measure for de-escalating hostilities. Next to that, threats of financial and economic disruptions are activated in conjunction with the military component of coercion, such as special operations forces.

For Russia, the destabilization factor is clearly more important than destruction. Currently, Russia seems to believe that conflict escalation in the Baltic countries is just a matter of time (Ploom, Sliwa and Veebel 2020). The possibility of a conflict escalation in the Baltic countries and Poland is very attractive for Russia, as far as the related costs and possible gains are compared. The development of NATO ballistic missile defense (BMD) from 2005 on and developments regarding the Treaty on Conventional Armed Forces in Europe (CFE) have given Russia additional self-justification to feel that they can make the first move next time. As there seem to be only very limited scenarios to deter Russia from conflict escalation in the Baltic countries, Russia is most likely busy with calculating the costs and gains of the conflict with absolute precision. For Russia, it is important who runs out of assets or moves in the chessboard, not the belief of what is right or wrong. The West seems not to be able to respond in a sufficiently comprehensive way because political control is weaker.

What would most likely convince Russia to stop destabilizing global security order is a situation where the West would respond to the same extent as the United States did after the 9/11 attacks. However, this would not be in accordance with the principles how the West would like to solve the conflict assuming the normative power of the European Union as well as the signals the NATO Alliance has until now sent out, stating that Russia is not considered as a threat. Although the Alliance has taken collective defense measures, for instance, in response to the situation in Syria and at the early stages of the Ukrainian conflict, those collective defense activities do not reach the measures the United States adopted after the 9/11 attacks.

Intriguingly, one of the potential "glass roofs" for Russia seems to be everything that relates to the image and reputation of the Russian political and military elite in Russia. On the one hand, as studies have shown the popularity of Russian political leaders increases as soon as the conflict breaks out. For example, immediately after the Georgian war, Putin's approval rating soared to 88 percent and slowly declined in the years that followed, during the period that lacked of aggressive, overwrought patriotism, and artificially motivated isolationist sentiment. Putin's approval rating remained low (about 63-65 percent) for several years and has increased only after tensions beak out in Ukraine and reached high levels (about 80-86 percent) after Russian military moves on the Crimean Peninsula. In the following two years since then, Putin has maintained an approval rating of more than 80 percent, spiking at 89 percent in June 2015 and at 88 percent in October 2015 after the start of the Syria operation (Kolesnikov 2016). On the other hand, any weakness of the Russian political leadership in terms of openly admitting that they are deterred by the West - if something like this should happen at some point - could constitute a turning point of the confrontation between Russia and the West. In more detail, there are historical examples where the rulers of Russia have been removed from power after "selling the fatherland for dimes." There are only some exceptions, e.g., in the times of Mikhail Gorbachev and Boris Yeltsin, when they both openly admitted Western supremacy and the need to comply with Western values and both remained in power. Thus, should the Russian leaders show any signs publicly that they are afraid and deterred, it could trigger the situation where the political elite of Russia cannot be trusted by Russians anymore. As a next step, this could potentially weaken the country and make it more confused, which would again make it more flexible in terms of finding 
compromise with the West. However, today this is rather a misperception to expect that Russian current leaders would do something like this because even if the Western military leaders could potentially find it benefit under certain circumstances to be deterred, the Russian leaders are mostly out of the game after they express first signs of hesitation. Whereas for the Western countries it seems to be more important to show themselves as moral victims suffering for the sake of common rules and even to ask forgiveness or show regret, then for Russia, it seems to be important to present itself as a winner, never to regret, and never to ask for forgiveness without any moral hesitations, if necessary.

\section{Conclusion: Key-Variables to Reduce the Risks and Improve the Communication between Russia and West}

Today, the policy-making discourses of both Moscow and the capitals of Western countries are full of mutual misperceptions, mirror imaging, and attribution of non-existent intentions and capabilities. Although the concepts of deterrence of Western countries and Russia partially overlap, there is also a huge area where they operate in "parallel universes." Furthermore, a lot of strategic culture in association with deterrence is produced not for operational or functional purposes, but to please local political or military elite.

To answer the question which improvements are needed in the future to actually deter Russia and to avoid further aggression on the Russian side, first, Russia can be deterred only in the language they understand: Russia needs to understand the threat, and it needs to have a meaning for them. Contemporary Russian strategic theory lacks any typology and classification of strategic gestures and their arrangements according to the logic of the escalation ladder, which, under some circumstances, may evolve into a dangerous political-military crisis. Russian political scientists hardly deal with these questions either. Furthermore, Russian strategic planners lack a codified procedure to estimate the conditions under which they would recommend to the senior leadership de-escalation by nuclear means. Russian experts have also argued that until recently they lacked methodology for calculating an unacceptable level of damage above which the nuclear threshold would be crossed.

Second, signaling seems to be highly important. Signaling goes mostly wrong for psychological reasons; instead of deterring them, we mobilize the opponent. In this respect, any possible "red lines" should be crossed without insulting the opponent. Moscow repeatedly expresses genuine frustration that the West attributes to Russia nonexistent strategic intentions in the Baltics, in Ukraine, and in Syria that the country actually does not have. Western responses following the Russian acts of coercion ran against Moscow's expectations and desired end result. The Russian approach presumes signaling, including intensified pressure across all domains, to communicate both the ability and capability of Russia to resolve. However, the question remains, to quote Kristin Ven Bruusgaard, "whether the adversary will understand the message of deterrence the way the Russian concept prescribes it" (Ven Bruusgaard 2016, 7-26). Amateurs can be found in both sides of the conflict. The current corpus of the Russian military literature does not thoroughly explore the subject of inadvertent escalation resulting from the misinterpretation of signaling. This neglect may delude Russian leaders about the effectiveness of cross-domain coercion as an effective tool against a range of challenges and place them on the brink of an apocalypse without their knowing it.

Moscow, similarly to the strategic communities elsewhere, seeks to signal or act coercively strongly enough to maintain, restore, or establish new norms of the opponent's strategic behavior, but without conflict escalation. In strategic theory, this is defined as a point of culmination, a situation in which the use of force has "reached its strongest possible position" and where strategists consider the termination of warfare to consolidate gains.

The concept of the so-called tailored deterrence strategy that is adapted to the nature of the specific actor is already a common wisdom. This study has shown that the understanding of deterrence strategies of different actors should be tailored as well. Emerging in a specific cultural context, the conceptualization of deterrence is not universal, but varies across strategic communities. Overall, this conclusion is in accordance with earlier theoretical findings suggesting that coercion, "theories of victory" and operational art are social constructions. Consequently, their conceptualization has national characteristics and may differ from Western strategic theory.

Western experts, when planning the long-term strategy, should take into account that Russians have basically two options when choosing between deterrence and strategic competition struggle: to follow Western paradigm that would mean playing by the rules of the West or to find an alternative model that might be not as sophisticated but that they could use with confidence and initiative. Understanding Russian strategic intensions is most vital (Adamsky 2018, 33-60).

The current Western rhetoric of "punishing Putin and the Kremlin and forcing them to respect Western demands" only unites Russian society to rally around the flag while also motivating Putin to maintain his current political line because of broad public support. The concepts of external governance or normative power have missed its 
own patronizing, neocolonial nature in respect to Russian values and culture, while the aim to dominate over the Russian values and Russia in general is clearly visible.

Assuming that Western countries would like to succeed in their actions and induce political and social changes in Russia, they need first to understand that national glory is one of the few virtues shared by the majority of the Russian population in all age and income groups. The process which is considered to be an "enlightenment" of Russia from the perspective of Western countries is today seen as a crusade of the West encroaching into Russia. Intriguingly, Russians are much less worried about the economic power of China mainly because it does not "attack" the Russian culture but are seriously worried about Western external governance and the doctrine of normative power in which Russia is a constantly targeted country that needs changes to become more civilized.

\section{References}

Adamsky, D. (2018). From Moscow with coercion: Russian deterrence theory and strategic culture. Journal of Strategic Studies, 41(1-2), 33-60. https://doi.org/10.1080/01402390.2017.1347872

BBC. (2018). Putin is inaugurated for fourth terms as Russian president. News, 7 May 2018. Retrieved April 21, 2019, from https://www.bbc.com/news/world-europe-44024184

Buzan, B. (1991). People, States and Fear: An Agenda for International Security Studies in the Post-Cold War Era (2nd Ed.). Boulder, CO: Lynne Reiner Publishers.

Elenkov, D. S. (1998). Can American management concepts work in Russia? A cross-cultural comparative study. California Management Review, 40(4), 133-156. https://doi.org/10.2307/41165968

European Commission. (2019). EU Neighbourhood region and Russia: International Cooperation and Development. Retrieved April 21, 2019, from https://ec.europa.eu/europeaid/regions/eu-neighbourhoodregion-and-russia_en

Frear, T., Kulesa, L., \& Raynova, D. (2018). Russia and NATO: How to overcome deterrence instability? European Leadership Network.

Friis, L., \& Murphy, A. (1999). The European Union and central and eastern Europe: Governance and boundaries. JCMS: Journal of Common Market Studies, 37(2), 211-232. https://doi.org/10.1111/1468-5965.00160

Gerrits, A. (2009). Normative Power Europe in a Changing World: A Discussion. In Introductory Observations on a Controversial Notion. 2009, Netherlands Institute of International Relations. Retrieved from https://www.clingendael.nl/sites/default/files/20091200_cesp_paper_gerrits.pdf

Hersman, R. (2017). The Deterrence and Assurance Conversation. Center for Strategic \& International Studies. Retrieved from https://www.csis.org/analysis/deterrence-and-assurance-conversation

Kolesnikov, A. (2016). Do Russians want war? Carnegie Moscow Center, June 2016. Retrieved from https://carnegieendowment.org/files/Article_Kolesnikov_2016_Eng-2.pdf

Lavenex, S. (2004). EU external governance in 'wider Europe. Journal of European Public Policy, 11(4), 680700. https://doi.org/10.1080/1350176042000248098

Loukianova Fink, A. (2017). The Evolving Russian Concept of Strategic Deterrence: Risks and Responses. Arms Control Association. Retrieved April 21, 2019, from https://www.armscontrol.org/act/201707/features/evolving-russian-concept-strategic-deterrence-risks-responses

Manners, I. (2002). Normative Power Europe: A Contradiction in Terms? Journal of Common Market Studies, 40, 2. https://doi.org/10.1111/1468-5965.00353

NATO (North Atlantic Treaty Organization). (2012). Active engagement, modern defence. Retrieved April 21, 2020, from https://www.nato.int/cps/ua/natohq/official_texts_68580.htm

NATO (North Atlantic Treaty Organization). (2015). NATO's nuclear deterrence policy and forces. Retrieved April 21, 2020, from https://www.nato.int/cps/en/natohq/topics_50068.htm

NATO (North Atlantic Treaty Organization). (2017). Strategic concepts. Retrieved April 21, 2020, from https://www.nato.int/cps/en/natohq/topics_56626.htm

Ploom, I., Sazonov, V., \& Veebel, V. (2019). Russia's pursuit of power in the Middle East: Context, strategy and methods. Estonian Journal of Military Studies, 11.

Ploom, I., Sliwa, Z., \& Veebel, V. (2020). The NATO 'Defender 2020' Exercise in the Baltic States: Will Measured Escalation Lead to Credible Deterrence or Provoke an Escalation? Comparative Strategy, 39(4), 368-384. https://doi.org/10.1080/01495933.2020.1772626 
Putin, V. (2014). Address by President of the Russian Federation. The Kremlin, Moscow, 18 March 2014. Retrieved April 21, 2020, from http://en.kremlin.ru/events/president/news/20603

Rahim, S. (2018). Revisiting Putin's 2007 Munich Security Conference Speech - Op-Ed. Eurasia Review: News \& Analysis. 11 September 2018. Retrieved April 21, 2020, from https://www.eurasiareview.com/11092018revisiting-putins-2007-munich-security-conference-speech-oped

Rogozin, D. (2011). Voina i Mir v Terminakh. Moscow: Vetche.

Russian National Security Strategy. (2015). Retrieved April 21, 2020, from http://www.ieee.es/Galerias/fichero/OtrasPublicaciones/Internacional/2016/Russian-National-SecurityStrategy-31Dec2015.pdf

Sliwa, Z., Veebel, V., \& Lebrun, M. (2018). Russian Ambitions and Hybrid Modes of Warfare. Estonian Journal of Military Studies, (7), 86-108.

Sokov, N. (2010). The New 2010 Russian Military Doctrine: The Nuclear Angle. Middlebury Institute of International Studies at Monterey 2010. Retrieved April 21, 2020, from https://www.nonproliferation.org/new-2010-russian-military-doctrine/

Timofeev, I. (2016). Russia and NATO in the Baltic. The Baltic Sea Region: Hard and Soft Security Reconsidered. 2016, Latvian Institute of International Affairs. Retrieved April 21, 2019, from $\mathrm{http} / / /$ liia.lv/en/publications/the-baltic-sea-region-hard-and-soft-security-reconsidered-558

Veebel, V. (2017). Russia's Neo-Imperial dependence model: Experiences of former Soviet republics. Romanian Journal of Political Science, 1(1).

Veebel, V. (2018). NATO options and dilemmas for deterring Russia in the Baltic States. Defence studies, 18(2), 229-251. https://doi.org/10.1080/14702436.2018.1463518

Veebel, V. (2019). European Union as normative power in the Ukrainian-Russian conflict. International Politics, 56(5), 697-712. https://doi.org/10.1057/s41311-018-0156-y

Veebel, V. (2020). Is the European Migration Crisis Caused by Russian Hybrid Warfare? Journal of Politics and Law, 13(2). https://doi.org/10.5539/jpl.v13n2p44

Veebel, V., \& Markus, R. (2016). At the Dawn of a New Era of Sanctions: Russian-Ukrainian Crisis and Sanctions. Orbis, 60(1), 128-139. https://doi.org/10.1016/j.orbis.2015.12.001

Veebel, V., \& Ploom, I. (2019). Are the Baltic States and NATO on the right path in deterring Russia in the Baltic?, Defense \& Security Analysis, 35(4), 406-422. https://doi.org/10.1080/14751798.2019.1675947

Veebel, V., \& Sliwa, Z. (2019). Kaliningrad, the Suwalki gap and Russia's ambitions in the Baltic Region. Journal of International Studies, 12(3). https://doi.org/10.14254/2071-8330.2019/12-3/9

Veebel, V., \& Vihmand, L. (2020). Living in confronting or parallel strategic narratives? The reasons behind the missing security dialogue between Russia and the Baltic States. Journal on Baltic Security, 5(2), 17-28. https://doi.org/10.2478/jobs-2019-0007

Veebel, V., Kulu, L., \& Tartes, A. (2014). Conceptual factors behind the poor performance of the European Neighbourhood policy. Lithuanian Foreign Policy Review, 31, 85-102.

Ven Bruusgaard, K. (2016). Russian Strategic Deterrence. Survival, 58(4), 7-26. https://doi.org/10.1080/00396338.2016.1207945

\section{Copyrights}

Copyright for this article is retained by the author(s), with first publication rights granted to the journal.

This is an open-access article distributed under the terms and conditions of the Creative Commons Attribution license (http://creativecommons.org/licenses/by/4.0/). 